CAHAYA PENDIDIKAN, 2(2): 229-241

Desember 2016

ISSN : 1460-4747

\title{
WACANA DAN KETIDAKMERATAN PEMBANGUNAN DI INDONESIA INEQUALLITY OF DISCOURSE AND DEVELOPMENT IN INDONESIA
}

\author{
Afrinel Okwita \\ Pendidikan Sejarah FKIP UNRIKA BATAM
}

aaftuteh@gmail.com

\begin{abstract}
Abstrak
Artikel ini bertujuan untuk mendeskripsikan tentang wacana ketidakmerataan pembangunan di Indonesia. Adapun temuan dalam artikel ini adalah pembangunan di Indonesia tidak terlepas dari wacana dan proses pembangunan. Proses pembangunan Indonesia merupakan suatu kegiatan yang terus menerus dan menyeluruh dilakukan mulai dari penyusunan suatu rencana, penyususnan pogram, kegiatan pogram, pengawasan sampai pada pogram terselesaikan.Namun pada kenyataannya proses pembangunan yang ada Indonesia tidak sesuai dengan tujuan pembangunan nasional. Selama ini cendrung terjadi ketimpangan atau ketidakcocokan antara wacana dan prakteknya. Sehingga pembangunan di Indonesia tidak merata masih terpusat pada daerah-daerah perkotaan. Negara ini juga belum dapat memanfaatkan wilayah-wilayah daerah pelosok yang memiliki potensi untuk membangun perekonomian Indonesia sehingga dapat menambah pendapatan Negara.
\end{abstract}

Kata Kunci: Wacana, Ketidakmerataan, Pembangunan di Indonesia.

\begin{abstract}
This article aims to describe the discourse on inequality of development in Indonesia. The findings in this article is the development in Indonesia can not be separated from the discourse and the development process. Indonesia's development process is an activity that is constantly and thoroughly carried out starting from the preparation of a plan, prepare the program, the activities program, the supervision to the terselesaikan.Namun Program is in fact the existing development process Indonesia is not in accordance with national development objectives. During this tends to happen inaccuracies or incompatibility between discourse and practice. So that the uneven development in Indonesia is still focused on urban areas. The country is also not yet able to take advantage of areas remote areas that have the potential to build Indonesia's economy so as to increase state revenue.

Keywords: Discourse, Inequality, Development in Indonesia.
\end{abstract}

\section{PENDAHULUAN}


Pembangunan Nasional merupakan rangkaian kegiatan yang meliputi seluruh kehidupan masyarakat bangsa, dan negara untuk melaksanakan tugas sebagaimana yang di amanatkan dalam Undang-Undang dasar 1945, yaitu "melindungi segenap bangsa dan seluruh tumpah darah indonesia memajukan kesejahtraan umum, mencerdaskan kehidupan bangsa, serta melaksanakan ketertiban dunia yang berdasarkan kemerdekaan, perdamaian abadi dan keadilan sosial Negara" .

Pembangunan nasional dilaksanakan secara berencana, menyeluruh, terpadu, terarah, bertahap dan berlanjut untuk memicu peningkatan kemampuan nasional dalam rangka mewujudkan kehidupan yang sejajar dan sederajat dengan bangsa lain yang maju. Indonesia juga termasuk salah satu Negara yang memiliki sumber daya alam yang melimpah dengan tingkat pertumbuhan penduduk yang tinggi. Seperti yang kita ketahui Pembangunan di Indonesia masih belum mencerminkan keadaan layaknya Negara yang kaya dan makmur. Sampai saat ini pun pembangunan masih berkonsentrasi di daerah pusat, meskipun keadaan seperti ini sangatlah jauh dari apa yang dicita-citakan dalam tujuan dari wacana nasional Indonesia mengenai usahausaha untuk pemerataan pembangunan.

Akibat dari kurangnya pemerataan pembangunan memang tidak begitu dirasakan oleh masyarakat yang tinggal di daerah yang mengalami pembangunan cukup pesat. Disebabkan karena segala kebutuhan hidup mereka relatif lebih mudah untuk didapatkan, seperti pelayanan kesehatan ataupun sarana pendidikan yang tersebar di mana-mana.

Hal diatas jauh berbeda apabila dibandingkan dengan daerah yang pembangunannya bisa dikatakan masih lamban, atau masih belum tersentuh oleh pemerintah. Keadaan seperti ini terlihat pada daerah-daerah di Indonesia yang masih terpencil. Mereka harus bersusah payah untuk mendapatkan fasilitas seperti layanan kesehatan, pendidikan atau fasilitas-fasilitas lainnya mengingat jumlahnya yang sangat minim dan tempatnya yang jauh dari pemukiman penduduk terpencil.

Jika kita lihat wacana pembangunan di indonesia berbagai macam prospek pembangunan telah dilakukan mulai dari Orde Lama hingga saat sekarang ini.

\footnotetext{
${ }^{1}$ Afrizalwszaini.wordpress.com. Diakses tanggal 25 Mei 2012
} 
Wacana pembangunan tersebut untuk terus mendorong kesejahteraan dan kemajuan bangsa kearah yang lebih baik. Dalam hal ini pembangunan nasional juga harus dimulai dari, oleh, dan untuk rakyat, dilaksanakan diberbagai aspek kehidupan bangsa yang meliputi politik, ekonomi, sosial budaya dan aspek pertahanan keamanan. Pembangunan nasional pada dasarnya sangat membutuhkan kesinergian antara masyarakat dan pemerintah. Masyarakat adalah pelaku utama dalam pembangunan dan pemerintah berkewajiban untuk mengarahkan, membimbing, serta menciptakan suasana yang menunjang. Kegiatan masyarakat dan kegiatan pemerintah harus saling menunjang, saling mengisi, saling melengkapi dalam memajukan masyarakat dan nasional pada umumnya.

Kenyataan bahwa penerapannya tidak sesuai dengan apa yang diharapkan oleh masyarakat indonesia. Adanya kesenjangan dan ketidakcocokan antara wacana dan praktek dari pembangunan tersebut. Sehingga menyebabkan ketidakmerataan pembangunan dan menjadi masalah yang belum pernah terselesaikan.

Indonesia sebagai negara yang sedang berkembang masih saja mengalami permasalahan di bidang pembangunan. Wacana pembangunan yang dilaksanakan secara berencana, menyeluruh, terpadu, terarah, bertahap dan berlanjut untuk memicu peningkatan kemampuan nasional dalam rangka mewujudkan kehidupan yang sejajar dan sederajat dengan bangsa lain yang maju. Indonesia juga termasuk salah satu Negara yang memiliki sumber daya alam yang melimpah dengan tingkat pertumbuhan penduduk yang tinggi. Namun kenyataannya dilapangan pembangunan di Indonesia masih belum mencerminkan keadaan layaknya Negara yang kaya dan makmur. Dimana terjadi ketidaksesuaian antara wacana dan praktek lapangan yang masih belum terselesaikan seperti banyaknya masyarakat miskin, gelandangan, pengemis dan anak-anak yang tidak bisa mengecap pendidikan.

Hal ini tentu menjadi suatu masalah yang sangat menyedihkan dan menjadi tanggung jawab kita bersama sebagai generasi penerus bangsa. Oleh sebab itu dalam 
artikel ini permasalahan yang penulis bahas yaitu Bagaimana wacana dan proses pembangunan di Indonesia serta faktor yang menyebabkan ketidakmerataan pembangunan selama ini, sehingga menjadi masalah yang belum pernah terselesaikan?

Adapun tujuan penulisan makalah ini adalah Untuk mendeskripsikan bagaimana proses pembangunan Indonesia dan faktor apa yang menyebabkan ketidakmerataan dalam pembangunan selama ini, sehingga menjadi masalah yang belum pernah terselesaikan.

\section{HASIL DAN PEMBAHASAN}

\section{Wacana dan Proses Pembangunan Indonesia}

Pembangunan adalah suatu proses perubahan yang direncanakan untuk menciptakan kesejahteraan dan memberikan alternatif kehidupan kepada masyarakat yang lebih luas. Pembangunan dapat disebabkan oleh dorongan yang berasal dari kebudayaan dan akan berakibat kepada masyarakat yang mendukung kebudayaan tersebut. Pembangunan di Indonesia tidak terlepas dari wacana dan proses pembangunan.

Ada dua elemen tidak diragukan lagi untuk menjelaskan situasi wacana pembangunan. $^{2}$

- Pengembangan alam semesta, ada kesenjangan yang lebar antara wacana dan praktek, apa yang dikatakan tentang proyek pembangunan saat ini adalah masalah konsep, pembentukan, format, perancangan, pembiayaan, atau membenarkan proyek tersebut memiliki banyak kesamaan dengan proyek itu sendiri sebagaimana yang ada di dalam praktek, setelah sampai ke tangan orang-orang yang dituju.

- Pengembangan alam semesta adalah salah satu aksi politik dalam arti luas, yaitu dalam arti niat untuk mengubah realitas dengan cara voluntaris. Hal ini

\footnotetext{
2 Jean-Pierre Olivier de Sardan. 2005. Anthropology and Development Understanding Contemporary Social Change. London \& New York: Zed Books. Hal 4
} 
karena alam semesta seperti alam semesta politik memakai kata penggunaan klik. Selanjutnya lembaga pengembangan berorientasi pada input, mereka harus meyakinkan donor dari kapasitas mereka untuk memberikan sumber daya.

Proses pembangunan Indonesia merupakan suatu kegiatan yang terus menerus dan menyeluruh dilakukan mulai dari penyusunan suatu rencana, penyususnan pogram, kegiatan pogram, pengawasan sampai pada pogram terselesaikan. Untuk lebih memahami wacana dan proses pembangunan di indonesia dapat dijelaskan dari beberapa aspek dibawah ini: ${ }^{3}$

\section{a. Perencanaan Pembangunan Indonesia}

Setelah terjadi berbagai goncangan ditanah air dan berbagai tekanan rakyat kepada presiden Soeharto, akhirnya pada tanggal 21 Mei 1998 Presiden Soeharto mengundurkan diri dari jabatannya sebagai presiden RI dan menyerahkan jabatannya kepada wakil presiden B.J. Habibie. Peristiwa ini menandai berakhirnya kekuasaan Orde Baru dan dimulainya Orde Reformasi. Untuk memperbaiki perekonomian yang terpuruk, terutama dalam sektor perbankan, pemerintah membentuk Badan Penyehatan Perbankan Nasional (BPPN). Selanjutnya pemerintah mengeluarkan UU No. 5 Tahun 1999 tentang Larangan Praktik Monopoli dan Persaingan Tidak Sehat, serta UU No. 8 Tahun 1999 tentang Perlindungan Konsumen.

Selain itu pada masa ini juga memberi kebebasan dalam menyampaikan pendapat, partisipasi masyarakat mulai terangkat kembali. Hal ini terlihat dari munculnya partai-partai politik dari berbagai golongan dan ideologi. Masyarakat bisa menyampaikan kritik secara terbuka kepada pemerintah. Di samping kebebasan dalam menyatakan pendapat, kebebasan juga diberikan kepada pers. Reformasi dalam

\footnotetext{
${ }^{3}$ Afrizalwszaini.wordpress.com. Diakses tanggal 23 Mei 2012
} 
pers dilakukan dengan cara menyederhanakan permohonan Surat Izin Usaha Penerbitan (SIUP).

Hadirnya reformasi pembangunan dapat di kontrol langsung oleh rakyat, dan kebijakan pembangunan didasari demokrasi yang bebunyi dari, oleh dan untuk rakyat, sehingga dengan dasar ini partisipasi rakyat tidak terkekang seperti pada masa orde baru, kehidupan perekonomian Indonesia dapat didorong oleh siapa saja. Selain pembangunan nasional pada masa ini juga ditekankan kepada hak daerah dan masyarakatnya dalam menentukan daerahnya masing-masing, sehingga pembangunan daerah sangat diutamakan keseriusan pemerintah pusat dalam melimpahkan wewenangnya kepada pemerintah daerah agar dapat menentukan pembangunan yang sesuai ratyatnya inginkan.

Dari penjelasan diatas sebagai arah perjalanan pembangunan Indonesia, arah tersebut telah menciptakan berbagai pembaharuan-pembaharuan untuk terus menuju kesejahteraan rakyat. Wacana pembangunan secara langsung atau tidak langsung dilaksanakan demi meningkatkan kecerdasan dan kemakmuran rakyat banyak. Khususnya dalam meningkatkan perekonomian Indonesia yang lebih baik.

Sistem kebijakan pembangunan di Negara Indonesia sudah menunjukkan perbaikan ke arah yang lebih demokratis. Semua proses pembangunan baik pusat maupun daerah dituntut supaya harus melibatkan publik dalam proses perencanaan, pelaksanaan hingga pengawasannya. Artinya partisipasi aktif masyarakat sipil sangat diperlukan dalam proses pembangunan Negara baik di tingkat pusat maupun daerah provinsi, kabupaten/kota, dan kecamatan. Hal ini menuntut kesadaran dan semangat masyarakat sipil seutuhnya sebagai warga Negara dan bangsa Indonesia yang turut bertanggung jawab dalam proses pembangunan Nasional.

\section{b. Kebijakan Ekonomi Dalam Pembangunan}

Pada masa krisis ekonomi, ditandai dengan tumbangnya pemerintahan Orde Baru kemudian disusul dengan era Reformasi yang dimulai oleh pemerintahan Presiden Habibie. Pada masa ini tidak hanya hal ketatanegaraan yang mengalami perubahan, namun juga kebijakan ekonomi. Sehingga apa yang telah stabil dijalankan 
selama 32 tahun, terpaksa mengalami perubahan guna menyesuaikan dengan keadaan.

Pemerintahan BJ.Habibie yang mengawali masa reformasi belum melakukan manuver-manuver yang cukup tajam dalam bidang ekonomi. Kebijakan-kebijakannya diutamakan untuk mengendalikan stabilitas politik. Pada masa kepemimpinan presiden Abdurrahman Wahid pun, belum ada tindakan yang cukup berarti untuk menyelamatkan negara dari keterpurukan. Padahal, ada berbagai persoalan ekonomi yang diwariskan orde baru harus dihadapi, antara lain masalah KKN (Korupsi, Kolusi dan Nepotisme), pemulihan ekonomi, kinerja BUMN, pengendalian inflasi, dan mempertahankan kurs rupiah. Malah presiden terlibat skandal Bruneigate yang menjatuhkan kredibilitasnya di mata masyarakat. Akibatnya, kedudukannya digantikan oleh presiden Megawati.

Masa kepemimpinan Megawati Soekarnoputri mengalami masalah-masalah yang mendesak untuk dipecahkan adalah pemulihan ekonomi dan penegakan hukum. Kebijakan-kebijakan yang ditempuh untuk mengatasi persoalan-persoalan ekonomi antara lain :

- Meminta penundaan pembayaran utang sebesar US\$ 5,8 milyar pada pertemuan Paris Club ke-3 dan mengalokasikan pembayaran utang luar negeri sebesar Rp 116.3 triliun.

- Kebijakan privatisasi BUMN. Privatisasi adalah menjual perusahaan negara di dalam periode krisis dengan tujuan melindungi perusahaan negara dari intervensi kekuatan-kekuatan politik dan mengurangi beban negara. Hasil penjualan itu berhasil menaikkan pertumbuhan ekonomi Indonesia menjadi $4,1 \%$. Namun kebijakan ini memicu banyak kontroversi, karena BUMN yang diprivatisasi dijual ke perusahaan asing.

Di masa ini juga direalisasikan berdirinya KPK (Komisi Pemberantasan Korupsi), tetapi belum ada gebrakan konkrit dalam pemberantasan korupsi. Padahal 
keberadaan korupsi membuat banyak investor berpikir dua kali untuk menanamkan modal di Indonesia, dan mengganggu jalannya pembangunan nasional.

Masa Kepemimpinan Susilo Bambang Yudhoyono terdapat kebijakan kontroversial yaitu mengurangi subsidi BBM, atau dengan kata lain menaikkan harga BBM. Kebijakan ini dilatar belakangi oleh naiknya harga minyak dunia. Anggaran subsidi BBM dialihkan ke subsidi sektor pendidikan dan kesehatan, serta bidangbidang yang mendukung peningkatan kesejahteraan masyarakat.

Kebijakan kontroversial pertama itu menimbulkan kebijakan kontroversial kedua, yakni Bantuan Langsung Tunai (BLT) bagi masyarakat miskin. Kebanyakan BLT tidak sampai ke tangan yang berhak, dan pembagiannya menimbulkan berbagai masalah sosial. Kebijakan yang ditempuh untuk meningkatkan pendapatan perkapita adalah mengandalkan pembangunan infrastruktur massal untuk mendorong pertumbuhan ekonomi serta mengundang investor asing dengan janji memperbaiki iklim investasi. Salah satunya adalah diadakannya Indonesian Infrastructure Summit pada bulan November lalu, yang mempertemukan para investor dengan kepala-kepala daerah.

Pada masa Reformasi dan saat sekarang ini proses pembangunan nasional memang sudah demokratis dan sudah memerankan fungsi pemerintah daerah dalam menjalankan pasipartisi rakyat daerahnya. Dengan otonomi daerah telah memberikan sumbangsi yang besar terhadap proses percepatan pembangunan nasional dan juga menjaminnya sistem demokrasi yang merakyat. Masyarakat diberi kebebasan memberikan dan berpartisipasi aktif untuk menyampaikan pendapat melalui sistem multi partai.

\section{c. Sistem Pemerintahan}

Sistem pemerintahan Indonesia saat sekarang ini berdasarkan sistem multi partai. Dengan adanya sistem multi partai yang adanya saat ini memberikan kebebasan untuk masyarakat indonesia untuk membentuk partai baru guna menyampaikan keluhan-keluhan melalui wakil rakyat. Kenyataannya di lapangan saat ini sistem multi partai hanya dijadikan sebagai sarana atau alat oleh para elit partai untuk memperoleh kedudukan di tingkat pemerintah. Setelah mereka berhasil 
menduduki jabatan yang mereka inginkan, yang terjadi bukanlah untuk menyampaikan aspirasi dan keluhan rakyat namun melakukan korupsi berjemaah seperti pemberitaan yang ada di media massa. Mereka lebih memperhatikan dan membuat anggaran untuk membeli sarana dan fasilitas mewah dibandingkan memperhatikan nasib rakyat miskin yang semakin hari semakin meningkat.

Jadi disini dapat disimpulkan bahwasannya Indonesia belum berhasil dalam pembangunan nasional. Meskipun Pemerintahan tidak punya kebijakan untuk menetapkan Presiden dan menuruti alur parpol di DPR, pemerintahan lemah, dan muncul otonomi daerah yang kebablasan, tidak jelas apa orientasinya dan mau dibawa kemana bangsa ini. Semuanya hanya cerita para pejabat negara hanya lebih mementingkan masalah pribadinya tampa memikirkan nasib rakyat miskin.

\section{Ketidakmerataan Pembangunan Indonesia}

Negara Indonesia merupakan Negara yang kaya akan sumber daya alam dan wilayahnya yang strategis. Sebagai Negara yang berkembang Indonesia juga melakukan usaha pembangunan semenjak masa reformasi sampai sekarang, pembangunan di Indonesia dapat dikatakan lebih maju terutama di daerah perkotaan yang pembangunannya relatif lebih cepat karena mengingat jumlah penduduk serta aktivitas di daerah perkotaan lebih banyak. Untuk mengatasi hal tersebut indonesia menerapkan sistem desentralisasi atau otonomi daerah untuk mengatasi persoalan dalam pembangunan. ${ }^{4}$

Desentralisasi adalah program yang baik, karena akan mendorong kemajuan, pertumbuhan, dan pemerataan bagi seluruh rakyat. Dalam paradigma pemerintahan lama yang sentralistik, maka aspirasi masyarakat daerah sulit untuk diserap sehingga menyebabkan pembangunan hanya terlihat pada daerah perkotaan saja. Dengan

\footnotetext{
${ }^{4}$ Dek-dila.blogspot.com. Diakses 23 Mei 2012
} 
desentralisasi, aspirasi rakyat di daerah semakin mudah untuk diserap dan dilaksanakan. ${ }^{5}$

Desentralisasi dilakukan dengan harapan supaya terjadi penataan kelembagaan pemerintah yang mengupayakan semakin dekatnya pelayanan publik dan keputusan-keputusan pembangunan ekonomi dengan kepentingan masyarakat dan pemerintah setempat. Artinya di sini bahwa kesenjangan antara aspirasi rakyat dengan wujud pelaksanaannya harus semakin kecil bahkan dapat dihilangkan. Hal ini menuntut kualitas wakil rakyat (yang berada di parlemen lokal dan nasional) dan aparat pemerintah daerah (pemda) untuk memformulasikan aspirasi masyarakatnya, dan mewujudkan dalam program-program pembangunan yang sesuai.

Namun kenyataanya masih banyak daerah-daerah yang kurang bahkan belum tersentuh pembangunan seperti yang berada di pelosok terpencil. Masih banyak ditemui daerah terpencil yang masih dilalui dengan jalan tanah dan belum masuknya listrik ke daerah tersebut. Sehingga apabila kita lihat secara keseluruhan pembangunan di negara Indonesia, sebenarnya masihlah sangat lambat dan sifatnya tidak merata. Pembangunan hanya dirasakan oleh daerah pusat dan banyak pemberitaan bahwa dana pembangunan hanya habis dikorupsi oleh para para pemegang kekuasaan.

Adapun Faktor penyebab Ketidakmerataan Pembangunan di Indonesia adalah sebagai berikut: ${ }^{6}$

a. Kurangnya perhatian pemerintah dalam menuntaskan masalah pemerataan pembangunan.

b. Pembangunan lebih banyak di fokuskan di daerah-daerah perkotaan

c. Kurangnya sifat kewirausahaan para pelaku pengembang ekonomi di wilayah

\footnotetext{
5 Tehusalawany. Reza. Dampak Wacana Pembangunan dan Desentralisasi bagi Daerah Tertinggal. [internet]. Dimuat dalam http://www.leimena.org/id/ dampak-wacana-pembangunan-dandesentralisasi-bagi-daerah-tertinggal. Diakses tanggal 18 Mei 2012.
}

${ }^{6}$ Dek-dila.blogspot.com. Diakses 23 Mei 2012 
d. Lokasi-lokasi Pulau pelosok terpencil yang sulit dijangkau.

e. Keterbatasan Jaringan ekonomi dalam mendukung pengembangan kawasan dan produk unggulan daerah.

f. Lemahnya kerjasama antara pelaku pengembangan kawasan seperti pemerintah, lembaga non pemerintah, swasta, dan masyarakat.

g. Ketidakseimbangan pasokan sumber daya alam dengan kegiatan pembangunan

Dari faktor yang menyebabkan ketidakmerataan pembangunan di indonesia dapat kita lihat bahwa, cita-cita bangsa kita untuk mensejahterakan masyarakat belum sepenuhnya terwujud mengingat pembangunan yang hanya terpusat di daerah pusat, bahkan cita-cita untuk mencerdaskan kehidupan bangsa tidak akan terwujud apabila tidak adanya pemerataan pembangunan fasilitas pendidikan. Karena pada dasarnya pendidikan merupakan salah satu hal yang terpenting demi mencapai keberhasilan suatu bangsa. Kenyataan dilapangan pemerintah lebih mementingkan kepentingan pribadinya dari pada menanggulangi permasalah masyarakat secara keseluruhan.

Sebagai fakta yang dapat kita ketahui, di salah satu media elektronik tertulis, Ketua DPRD Jabar Irfan Suryanagara mengakui bahwa pembangunan di Jabar belum merata. Kondisi tersebut terjadi akibat Pemprov dan DPRD Jabar belum optimal mendesain APBD. "Selama ini APBD disusun tanpa menggunakan data, akibatnya pembangunan hanya dilakukan berdasarkan perkiraan. Hal ini terlihat bahwa jelas bahwasan pembangunan di Indonesia tidak merata. Adanya kecurangan yang dilakukan oleh Pemerintah dalam mendesain APBN sehingga nantinya dikorupsi dan menjadi uang pribadi. Hal semacam inilah yang terus-menerus dilakukan oleh wakil rakyat tampa menjalankan tugasnya untuk menciptakan kesejahteraan masyarakat banyak. 
Dampak yang ditimbulkan dari ketidakmerataan pembangunan di Indonesia adalah:

a. Keterbelakangan pada Masyarakat terpencil

Dampak ketidakmerataan pembangunan tidak begitu dirasakan oleh masyarakat perkotaan yang tinggal di daerah yang mengalami pembangunan pesat, karena segala kebutuhan hidupnya lebih mudah didapat seperti fasilitas pendidikan dan kesehatan, sangat jauh berbeda bila dibandingkan dengan masyarakat yang tinggal di daerah terpencil, mereka sangat kesulitan dalam mengakses fasilitas pendidikan atau kesehatan yang dibangun pemerintah, selain jumlahnya sedikit, letaknya pun yang kebanyakan jauh dari pemukiman sehingga banyak masyarakat terpencil yang enggan mengaksesnya.

b. Pendapatan Negara Tidak maksimal

Pendapatan Negara tidak maksimal dikarenakan pembangunan yang tidak merata itu menyebabkan kurangnya pemanfaatan sumber daya alam dari daerah yang memiliki potensi ekonomi yang baik untuk jangka ke depannya.

\section{KESIMPULAN DAN SARAN}

\section{a. Kesimpulan}

Pembangunan di Indonesia tidak terlepas dari wacana dan proses pembangunan. Proses pembangunan Indonesia merupakan suatu kegiatan yang terus menerus dan menyeluruh dilakukan mulai dari penyusunan suatu rencana, penyususnan pogram, kegiatan pogram, pengawasan sampai pada pogram terselesaikan.

Namun pada kenyataannya proses pembangunan yang ada Indonesia tidak sesuai dengan tujuan pembangunan nasional. Selama ini cendrung terjadi ketimpangan atau ketidakcocokan antara wacana dan prakteknya. Sehingga pembangunan di Indonesia tidak merata masih terpusat pada daerah-daerah perkotaan. Negara ini juga belum dapat memanfaatkan wilayah-wilayah daerah 
pelosok yang memiliki potensi untuk membangun perekonomian Indonesia sehingga dapat menambah pendapatan Negara.

\section{b. Saran}

a. Di harapkan kepada generasi penerus bangsa agar mampu dan terus bersaing dalam mewujudkan Indonesia bebas dari kemiskinan dan memeratakan pembangunan Indonesia.

b. Pemerintah dalam hal ini harus lebih memperhatikan wilayah terpencil dan mengusahakan pembangunan secara maksimal, membuat kebijakan-kebijakan yang dapat menunjang pembangunan.

\section{DAFTAR PUSTAKA}

B S Muljana.2001.Perencanaan Pembangunan Nasional. Jakarta:UI-Press.

Jean-Pierre Olivier de Sardan. 2005. Anthropology and Development Understanding Contemporary Social Change. London \& New York: Zed Books.

Afrizal. Zaini. Pembangunan indonesia dari masa orde lama, orde baru sampai era reformasi. [internet]. Dimuat dalam http://www.wordpress.com Pembangunan- Indonesia- dari masa orde lama- orde baru - sampai era reformasi. Diakses tanggal 23 Mei 2012.

Dek. Dilla. 2012. Paper Pembangunan di Indonesia. [internet]. Dimuat dalam http://www.blogspot.com Paper- Pembangunan-di Indonesia. Diakses tanggal 23 Mei 2012.

Tehusalawany. Reza. Dampak Wacana Pembangunan dan Desentralisasi bagi Daerah Tertinggal. [internet]. Dimuat dalam http://www.leimena.org/id/ dampakwacana-pembangunan-dan-desentralisasi-bagi-daerah-tertinggal. Diakses tanggal 18 Mei 2012. 
Afrinel:Wacana Dan Ketidakmeratan Pembangunan Di Indonesia............ 